\title{
Influence of Key Strata on the Gas Downward Leakage Law in Dual-System of Coal Seam
}

\author{
Feng Du, ${ }^{1}$ Kun Jiao, ${ }^{1}$ and Zhanyuan $M a \mathbb{D}^{2}$ \\ ${ }^{1}$ School of Energy Science and Engineering, Henan Polytechnic University, Jiaozuo, 454000 Henan, China \\ ${ }^{2}$ Datong Coal Mine Group Co. Ltd., Datong, 037003 Shanxi, China \\ Correspondence should be addressed to Zhanyuan Ma; 455985723@qq.com
}

Received 24 May 2020; Revised 28 June 2020; Accepted 27 August 2020; Published 10 September 2020

Academic Editor: Guozhong Hu

Copyright (C) 2020 Feng Du et al. This is an open access article distributed under the Creative Commons Attribution License, which permits unrestricted use, distribution, and reproduction in any medium, provided the original work is properly cited.

\begin{abstract}
In Datong mining area, CO and other harmful gases were discharged from the gob in the Jurassic overburden strata to the panel of Carboniferous coal seam. To this end, panel 8309 of Tongxin coal mine in Datong mining area was taken as the engineering background; the change law of CO concentration in the upper corner of the panel and the law of mining pressure were studied through field measurement, and the influence of periodic movement of key strata on the downward leakage law of harmful gases was analyzed. In this paper, the fracture law of the key strata and fracture development characteristics of overburden strata were further studied by the similar simulation test, and the influence of the periodic movement of the key strata on the pathway formation of gas downward leakage was analyzed. The results show that the main cause of harmful gas downward leakage in the Jurassic gob is through the fracture produced by the fracture of the higher key strata. If the higher key strata fractures in the coal mining in the Carboniferous system, through fracture connecting the Jurassic gob above the open-off cut and the upper part of the panel are formed, and effective pathways for gas downward leakage are generated. The fracture and rotation of the higher key strata are accompanied by the formation and disappearance of the effective pathway for gas downward leakage above the panel. Then the periodic change of harmful gas discharging to the panel is caused and consistent with the law of mining pressure.
\end{abstract}

\section{Introduction}

Datong mining area has both Jurassic and Carboniferous coal seams. At present, the upper Jurassic coal resources are almost exhausted, and the lower Carboniferous ultra-thick coal seam has become the main coal seam for the mining $[1,2]$. Carboniferous coal seam is usually mined with a large thickness, and the damage area of the rock strata is usually enlarged with the highly developed mining fractures [3]. As a result, fractures are easily interacted with the gob in Jurassic coal seam (abbreviated as Jurassic gob) and Carboniferous coal seam; and the downward leakage of harmful gases (such as CO) can be caused from the Jurassic gob, which seriously affects the safe and efficient mining of the Carboniferous coal seam [4].

The downward leakage of harmful gas in the Jurassic gob is mainly caused by the mining-induced fracture in the interval strata of the dual-system coal seam. Many scholars have studied the development law of overburden breakage charac- teristics and mining-induced fracture in overburden strata. Bai and Lsworth [5] and Palchik [6] verified that there were three different moving zones in longwall mining overburden rock, namely, the caving zone, the fracture zone, and the bending deformation zone. Liu [7] systematically studied and summarized the deformation and failure of mininginduced overburden strata in coal mines of China. Besides, the calculation equations of the development height of water-conducting fracture zone were obtained [8-10]. Singh and Kendorski [11] put forward the importance of the waterretaining rock formation between water body and gob in 1981. This work plays an important guiding role in the safe mining of coal seam under water body. However, the influence of the overburden structure, fracture type, and the whole movement of the strata on the development of the water-conducting fracture are not considered in these researches. Qian et al. [12] proposed the theory of key strata control and concluded that the key strata play a decisive role in controlling the strata movement and the development of 
mining fracture. Ju and $\mathrm{Xu}$ [13] and Li et al. [14] studied the structural characteristics of the key strata of longwall face in fully mechanized mining and its influence on mine pressure. Zhang et al. [15] and Kuang et al. [16] determined the law of fracture and movement of key strata through in situ investigation. Based on the key strata theory, Miao et al. [17], Wang et al. [18] and Feng et al. [19] proposed the concept and principle of the water-resisting key strata for the mining with water preservation, established a mechanical model of the composite water-resisting key strata, and successfully applied it to the prevention and control of water inrush disaster of roof and floor and the protection of water resources in mining area [20]. Based on the theory of key strata, Xu et al. [21] and Wang et al. [22] studied the influence of the location of the main key strata of the overburden strata on the development height of the water-conducting fracture and proposed a prediction method for the height of the water-conducting fracture zone by the location of the key strata of the overburden strata [23]. Du et al. [24] analyzed the development patterns of fractured water-conducting zones in longwall mining of thick coal seams according to the safety mining of Zhuozhang river. $\mathrm{Tu}$ and $\mathrm{Fu}$ [25], Qu et al. [26], and $\mathrm{Wu}$ [27] performed the research on the gas migration pathway in the coal seam and obtained the influence of key strata on the effect and scope of gas drainage. Besides, the reliability of key strata theory applied in gas extraction was verified by field engineering application. In addition, Ma et al. [28] studied the characteristics of water flow in mining fractured rock mass. $\mathrm{Si}$ et al. [29], Zhao et al. [30], and Wang et al. [31] presented a systematic investigation into the permeability characteristics of flow field in mining area.

At present, many scholars have studied the development law of overburden breakage characteristics and mininginduced fracture in overburden strata, and the mining thickness of coal seam is below $8 \mathrm{~m}[32,33]$. However, the average thickness of Carboniferous ultra-thick coal seam in Datong mining area is $15 \mathrm{~m}$, and the damage area of the rock strata is usually enlarged with the highly developed mining fractures $[34,35]$. The downward leakage of harmful gas in the Jurassic gob is mainly caused by the mining-induced fracture in the interval strata of the dual-system coal seam [36-38]. Therefore, the research on the development law of overburden breakage characteristics and mining-induced fracture in Datong mining area should be carried out systematically.

To summarize, the key strata theory has been well applied in the development law of water-conducting fracture zone and the mining-induced fracture evolution related to gas drainage. In view of the occurrence and mining conditions of the dual-system coal seams in Datong mining area, panel 8309 of Tongxin mine, Datong mining area was taken as the research background; the key strata theory, physical experiment, and field measurement were used to study the fracture law and fracture development characteristics of the interval strata of the dual-system coal seam. Besides, the influence of the periodic movement of the key strata on the gas downward leakage pathway and gas drainage law was analyzed, so as to ensure the safe and efficient mining of the dual-system coal seams. This study provides a theoretical guidance for coal mining in the dual-system coal seam.

\section{Introduction of Panel and Identification of Key Strata}

2.1. Overview of the Panel. Panel 8309 of Tongxin mine is located in the third mining area of Tongxin mine in Datong mining area. The 3-5\# coal seams of the Carboniferous system were mined. The average thickness of the coal seam was $14.88 \mathrm{~m}$, the average buried depth was $580 \mathrm{~m}$, and the dip angle was $0-3^{\circ}$. The length of the panel was $2843 \mathrm{~m}$, and the dip length was $200 \mathrm{~m}$. Longwall mining and the extraction ventilation method was adopted. Jurassic gob in 14\# coal seam was overlaid on the panel 8309 , with a spacing of 200 $240 \mathrm{~m}$. There were a lot of water and harmful gas in the Jurassic gob, which seriously affected the safe and efficient mining of the panel. The goaf in Jurassic coal seam above the panel 8309 from the open-off cut to $1283 \mathrm{~m}$ includes the panel 81003 , the panel 81005 , the panel 81006, and the panel 81008 ; besides, the goaf in Jurassic coal seam above the panel 8309 from $1809 \mathrm{~m}$ to the nonmining line includes the panel 8902-3, the panel 8902-2, the panel 8908, and the panel 8906 .

2.2. Key Strata Identification. According to the key strata theory of strata control and the water-resisting key strata theory for mining with water conservation [8], the stability of key strata in the interval strata of dual-system coal seam plays a decisive role in the gas drainage in the overburden gob. The key strata refer to the strata which control the whole or partial overburden movement from the overburden to the surface. If the structural key strata do not fracture after mining, the fracture cannot expand, develop, or form an effective gas drainage pathway. Therefore, the structural key strata is the gas-resisting key strata. To study the influence of the key strata between the dual-system coal seams on the harmful gas downward leakage of the overburden gob, the core drilling holes were arranged in the middle of the panel 8309. Mechanical parameters of the standard coal rock samples were tested by RMT-150B rock mechanics experiment system, and the position of the key strata of the overburden strata on the panel was determined according to the key strata discrimination condition [7], as shown in Table 1.

It can be seen from Table 1 that the immediate floor of the panel is composed of sandy mudstone with a thickness of $4 \mathrm{~m}$, and the immediate roof is mainly composed of coarse-grained sandstone and sandy mudstone. There is the Jurassic gob in 14\# coal seam and $220.89 \mathrm{~m}$ above the panel, and there are two key strata in the overburden strata. The higher key strata are $123.08 \mathrm{~m}$ away from the 3-5\# coal seams, which is less than 10 times of the mining height. According to the prediction method for the height of the water-conducting fracture zone proposed by $\mathrm{Xu}$ et al. [21], the harmful gas of Jurassic gob in 14\# coal seam will be discharged to the panel 8309 after the key strata are broken.

\section{Experimental Analysis of Periodic Movement of Key Strata and Gas Downward Leakage}

3.1. CO Observation Schemes of Panel 8309. To study the gas downward leakage law of the Jurassic gob in 14\# coal seam 
TABLe 1: Physical and mechanical parameters of 1\# drill hole column and coal seams.

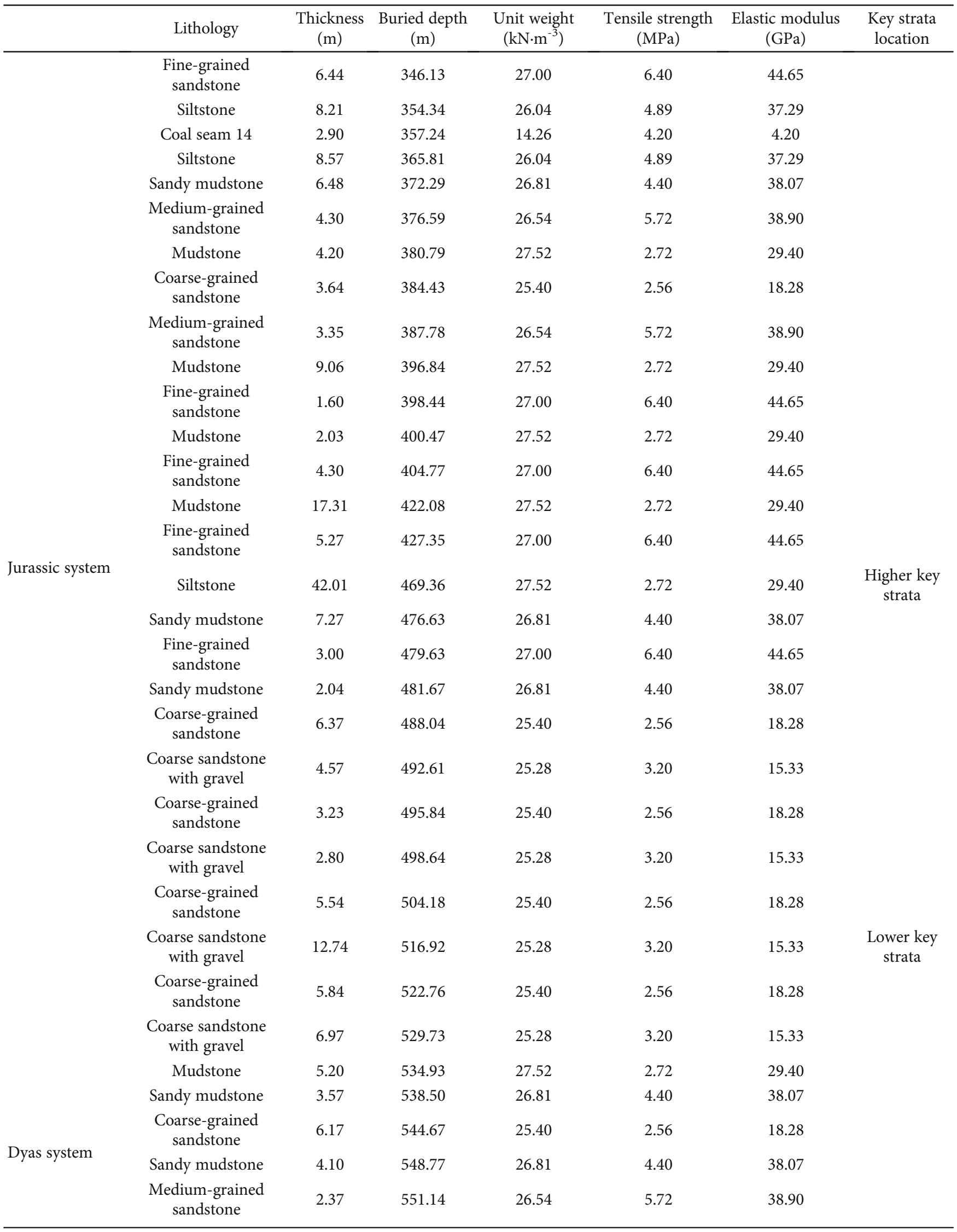


TABLe 1: Continued.

\begin{tabular}{|c|c|c|c|c|c|c|c|}
\hline & Lithology & $\begin{array}{l}\text { Thickness } \\
(\mathrm{m})\end{array}$ & $\begin{array}{c}\text { Buried depth } \\
(\mathrm{m})\end{array}$ & $\begin{array}{l}\text { Unit weight } \\
\left(\mathrm{kN} \cdot \mathrm{m}^{-3}\right)\end{array}$ & $\begin{array}{c}\text { Tensile strength } \\
(\mathrm{MPa})\end{array}$ & $\begin{array}{c}\text { Elastic modulus } \\
(\mathrm{GPa})\end{array}$ & $\begin{array}{c}\text { Key strata } \\
\text { location }\end{array}$ \\
\hline & $\begin{array}{l}\text { Coarse-grained } \\
\text { sandstone }\end{array}$ & 2.40 & 553.54 & 25.40 & 2.56 & 18.28 & \\
\hline & Sandy mudstone & 5.94 & 559.48 & 26.81 & 4.40 & 38.07 & \\
\hline & $\begin{array}{c}\text { Coarse-grained } \\
\text { sandstone }\end{array}$ & 3.10 & 562.58 & 25.40 & 2.56 & 18.28 & \\
\hline & Mudstone & 6.74 & 569.32 & 27.52 & 2.72 & 29.40 & \\
\hline & Sandy mudstone & 1.87 & 571.19 & 26.81 & 4.40 & 38.07 & \\
\hline & $\begin{array}{l}\text { Coarse-grained } \\
\text { sandstone }\end{array}$ & 5.34 & 576.53 & 25.40 & 2.56 & 18.28 & \\
\hline \multirow{3}{*}{$\begin{array}{l}\text { Carboniferous } \\
\text { system }\end{array}$} & Sandy mudstone & 1.60 & 578.13 & 26.81 & 4.40 & 38.07 & \\
\hline & Coal seams 3-5 & 14.05 & 592.18 & 14.26 & 4.20 & 4.20 & \\
\hline & Sandy mudstone & 4.00 & 596.18 & 26.81 & 4.40 & 38.07 & \\
\hline
\end{tabular}

above the panel 8309, CO was taken as the monitoring object of the discharged gas, and 8 observation points for $\mathrm{CO}$ concentration were designed and arranged in panel 8309, headgate 2309, and tailgate 5309. As shown in the Figure 1, 4 measuring points for $\mathrm{CO}$ concentration are uniformly arranged in the $200 \mathrm{~m}$ long panel. The exact time for field measurement is from June 14, 2018, to July 13, 2018. Measuring points 1 and 4 correspond to the upper and lower corners of the panel, and two measuring points are arranged $50 \mathrm{~m}$ and $100 \mathrm{~m}$ away from the upper and lower corners of headgate 2309 and tailgate 5309. CO concentration of each measuring point is monitored in real time through the $\mathrm{CO}$ volume concentration sensor, as shown in Figure 2.

3.2. Effect of Periodic Movement of Key Strata on Gas Downward Leakage. Through the CO concentration of each observation point, it is found that CO of the Jurassic gob in $14 \#$ coal seam is discharged to panel 8309 under the negative pressure effect. Since the upper corner is located at the return side of the panel and close to the triangle area of the upper side of the return air lane and the edge of the gob, the CO concentration of the upper corner is significantly affected. Based on the monitoring results of $\mathrm{CO}$ concentration in the upper corner of the panel from June 13 to 14 and the mining pressure curve obtained by the 58\# support in the middle of the panel, the influence of periodic movement of key strata on gas downward leakage is analyzed. As shown in Figure 3, there are large and small periods of mining pressure in the advance of the panel. The small periodic mining pressure steps are measured as $24 \mathrm{~m}, 40 \mathrm{~m}, 34 \mathrm{~m}$, etc., and the average pressure steps are $33 \mathrm{~m}$; the large periodic pressure steps are measured as $64 \mathrm{~m}, 58 \mathrm{~m}$, etc., and the average pressure steps are $61 \mathrm{~m}$. The large periodic mining pressure steps are about twice of the small periodic mining pressure. The change of $\mathrm{CO}$ concentration in the upper corner presents periodic change, which is consistent with the law of mining pressure law. In the case of nonperiodic and small periodic mining pressure, $\mathrm{CO}$ concentration is low, while in the large periodic mining pressure, $\mathrm{CO}$ concentration increases significantly.
According to the drilling column in Table 1 and the theory of mining pressure and strata control [7], the main reason for the large and small periodic mining pressure in the panel is that there are two key strata in the overburden strata of the panel. When the lower key strata are broken, a small periodic mining pressure is formed, and when the lower key strata and the higher key strata are broken simultaneously, the large periodic mining pressure is formed. In the mining process of the dual-system coal seam, mininginduced fractures are generated in the interval strata, and harmful gas can be discharged to the Carboniferous panel through the gas leakage pathway formed by mining fractures. Because the key strata control the evolution of mining fractures, it can be inferred that the periodic fracture of the higher key strata will change the gas leakage pathway, thus causing the periodic leakage of the harmful gas from the Jurassic gob.

\section{Similar Simulation Experiments of Fracture and Fracture Development in Key Strata}

4.1. Design of Similar Simulation Experiments. To further study the influence of the periodic movement of the key strata on the evolution characteristics of the gas leakage pathway and the gas leakage law, a similar simulation experiment of the key strata fracture and fracture development law was performed based on the project background of the panel 8309. In this similar simulation experiment, a similar model frame with the size of $2.5 \times 1.3 \times 0.2 \mathrm{~m}$ (length $\times$ height $\times$ width) was selected. The geometric similarity ratio of the model was $200: 1$, the actual laying height was $1.28 \mathrm{~m}$, and the simulated laying height was $256.49 \mathrm{~m}$. The unit weight ratio of the model was $1.5: 1$, so the stress similarity ratio of the model was $300: 1$, the thickness of the nonsimulated overburden was $339.69 \mathrm{~m}$, and the load on the upper part of the model was $0.028 \mathrm{MPa}$. For test materials, sand was taken as aggregate; cement, calcium carbonate, and gypsum as cementing materials; borax as retarder; and mica as layered materials.

The theoretical basis for the similar simulation experiment includes the geometric similarity, the kinematic 


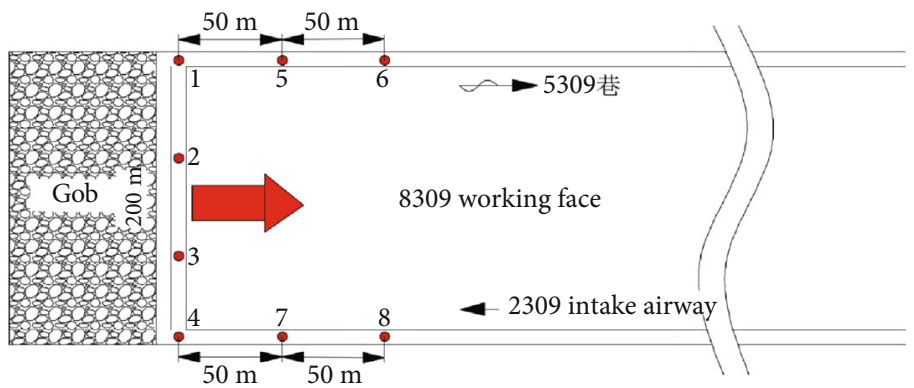

Figure 1: Layout of CO measuring points in panel 8309.

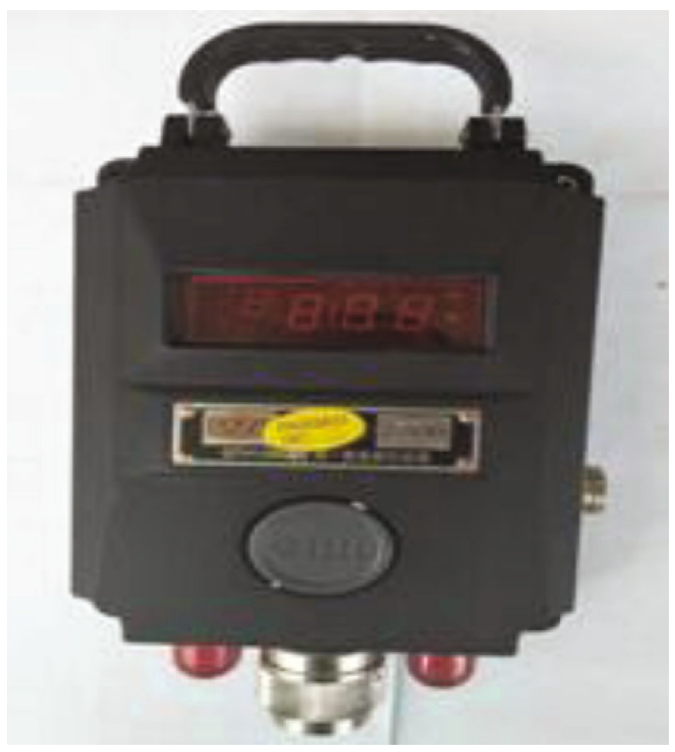

Figure 2: CO volume concentration sensor.

similarity, and the dynamic similarity. The similar simulation model is shown in Figure 4. To clearly observe the fracture development characteristics of 3-5\# coal seams and interval strata of 14\# coal seam during the excavation, after the model was laid, the coal seam and key strata were colored with black paint and yellow paint, respectively, on the front of the model, and the remaining strata were whitewashed with lime. At the same time, the grid lines with a spacing of $10 \mathrm{~cm}$ were drawn with ink bucket.

4.2. Experimental Processes and Experimental Results. Before the excavation, the model was loaded with a loading of $0.028 \mathrm{MPa}$. To reduce the boundary effect of the model platform, $30 \mathrm{~cm}$ protective pillars were reserved at both ends of the coal seam. In the model, 14\# coal seam was first mined, then 3-5 \# coal seams, all of which were excavated from the left side of the model at $5 \mathrm{~cm}$ every 30 minutes.

Similar simulation experiment results show that during the excavation of 3-5\# coal seams, the fracture of the key strata is accompanied by the movement of the loaded overburden strata and the fracture development. As shown in Figure 5, when the lower key strata is fractured, and a through fracture is formed, the overburden strata controlled by the key strata break synchronously, and the fracture develops rapidly to the lower part of the higher key strata; when the higher key strata fractures, longitudinal cracks are developed from the overburden strata to 14 \# coal floor. Through the analysis of the experimental results, it is believed that the lower layer of the key strata directly collapses during the advance of the panel, and the stability of the key strata is determined by the fracture and fracture development of the interval strata in the dual-system coal seam. Therefore, the two key stages of the fracture of the lower and higher key strata are analyzed based on experimental results.

4.2.1. Fracture of Lower Key Strata. When the panel is mined $60 \mathrm{~m}$ from the open-off cut, the first collapse of the direct roof occurs. With the panel advances to $120 \mathrm{~m}$, the fracture height of overburden strata reaches to the lower key strata, and separation zone appears at the bottom of the panel and gradually expands with the advance of the panel. When the panel is mined to $160 \mathrm{~m}$, the lower key strata fractures for the first time. As shown in Figure 6(a), due to the long settlement time in the separation zone near the open-off cut and the large compaction degree of the rock layer, the lower key strata presents an asymmetric fracture structure, and some of the above rock layer collapse. With the primary fracture of the lower key strata, longitudinal fracture runs through the lower key strata and develops to the lower part of the unbroken layer with the separation zone. At this time, the longitudinal fractures and separation zones on both sides are connected with each other, resulting in trapezoidalshaped collapse in the model.

When the panel is mined to $200 \mathrm{~m}$, the first periodic fracture occurs in the lower key strata, and the overburden strata collapse completely. At the same time, the separation zone and longitudinal fracture develop rapidly to the lower part of the higher key strata, as shown in Figure 6(b). With the advance of the panel, the periodic fracture continues to occur in the lower key strata, with an average periodic fracture step distance of $30 \mathrm{~m}$. Because the higher key strata are not broken, the development of the fracture upward is hindered, and the trapezoidal-shaped collapse area of the rock strata evolves towards the panel instead of the higher key strata. The floor failure in Jurassic coal seam has the important effect on gas downward leakage, because the mining fractures caused by the floor failure in Jurassic coal seam are the main leakage channel for the harmful gas. 


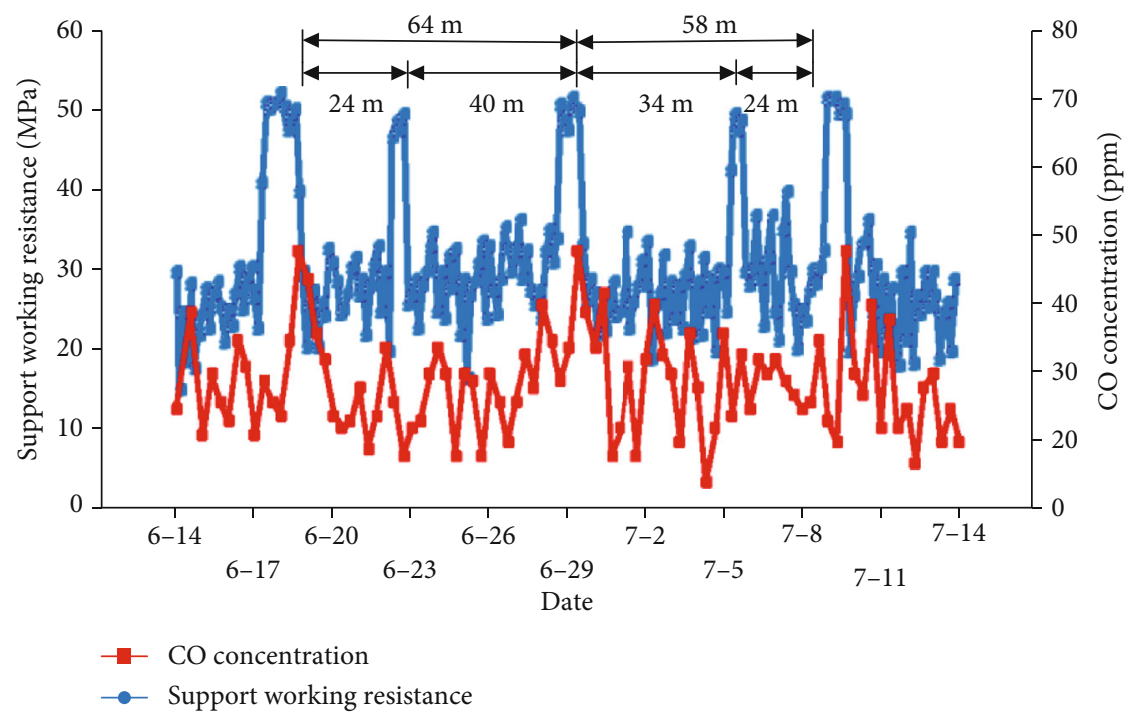

FIGURE 3: CO concentration and mining pressure curve in the upper corner of the panel.

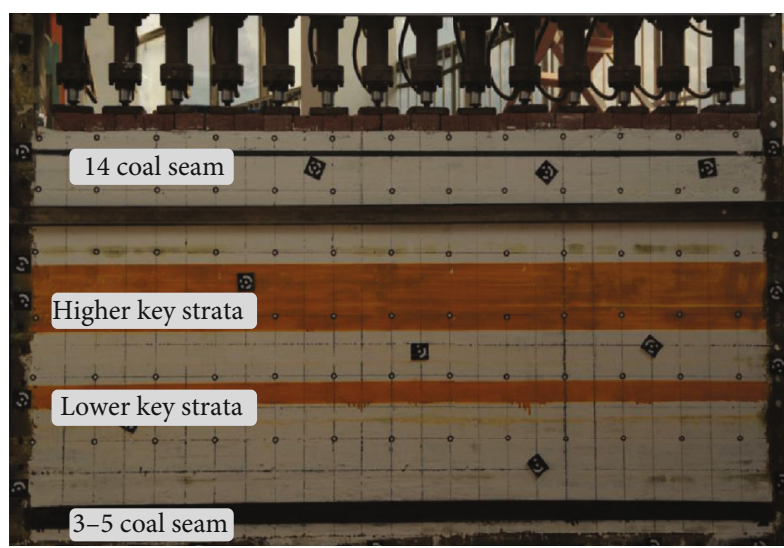

FIgURE 4: Similar simulation model.

4.2.2. Higher Key Strata Fracture. The fracture characteristics of the higher key strata in the mining process of the panel are shown in Figure 7. When the panel is mined to $300 \mathrm{~m}$, the higher and the lower key strata fracture simultaneously. With the first fracture of the higher key strata, the bottom strata of the gob in 14\# coal seam, which is controlled by the higher key strata, are fractured simultaneously. Meanwhile, the cracks in the overburden strata of the higher key strata develop rapidly to the bottom of the gob in the 14\# coal seam, and three longitudinal through cracks connecting the gob in 14\# coal seam are formed above the cut-out hole and the panel, as shown in Figure 7(a). Due to the large compaction degree of rock at the cut-out hole side, through crack 2 is inclined to the one side of the cut-out hole. When the panel advances to $360 \mathrm{~m}$, the first periodic fracture occurs in the higher key strata, with a step distance of about $60 \mathrm{~m}$. At the same time, a new through fracture is formed above the panel, as shown in Figure 7(b).

According to the main characteristics of fracture and fracture development of key strata in the excavation process of model, it is obtained that the periodic fracture step distance of the lower and higher key strata in the mining process of panel 8309 is about $30 \mathrm{~m}$ and $60 \mathrm{~m}$, respectively; the fracture step distance of higher key strata is twice that of lower key strata, which is basically consistent with the large and small periodic mining pressure curve of 58\# support in the middle of panel.

In the coal mining of Carboniferous system, through fractures caused by the fracture of the higher key strata is the main cause of the downward leakage of harmful gas in Jurassic gob. The phenomenon of key layer rotation and crack closure occurs in the similar simulation experiment results, which is controlled by the higher key strata. If the higher key strata fracture after the panel of Carboniferous system is fully mined, a through fracture connecting the Jurassic gob will be formed above the cut-out hole and the upper part of the panel, resulting in the generation of harmful gas leakage pathway. With the periodic fracture of the higher key strata, a new through fracture appears above the panel, becoming a new gas downward leakage pathway.

\section{Analysis of the Influence of the Key Strata on the Gas Downward Leakage Law in the Mining of Dual-System Coal Seam}

5.1. Influence of Key Strata on Evolution Law of GasConducting Fractures. In general, there are multiple key strata in the coal seam of the dual-system. Based on the theory of key strata, the evolution law of the gas-conducting fracture is analyzed when there are two key strata in the overburden. In the excavation of 3-5\# coal seams of Carboniferous system, when the lower key strata fractures with the advance of the panel, the lower key strata are located in the open-off cut, and the broken rock block above the panel rotates. The two ends of the gyratory block are occluded with the adjacent key strata or broken rock block to form four gasconducting fractures. With the fracture of the lower key strata, the soft rock layer in the control area overlying the 


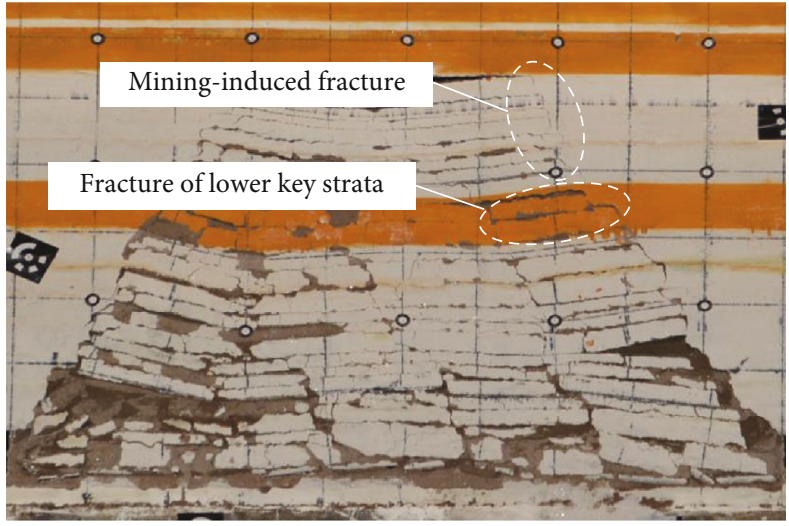

(a) Fracture of lower key strata

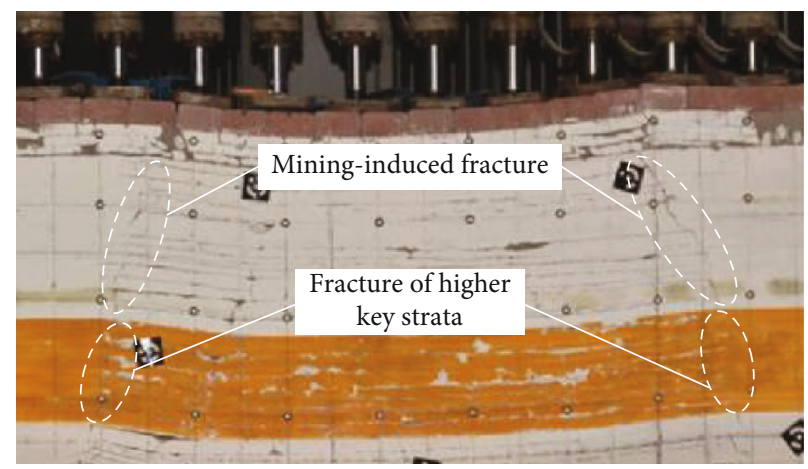

(b) Fracture of higher key strata

Figure 5: Simultaneous fracture of key strata and overburden strata.

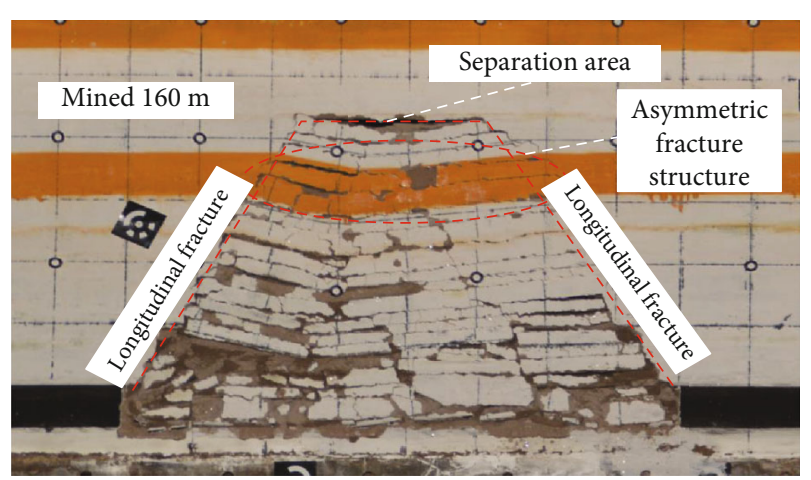

(a) Primary fracture of the lower key strata

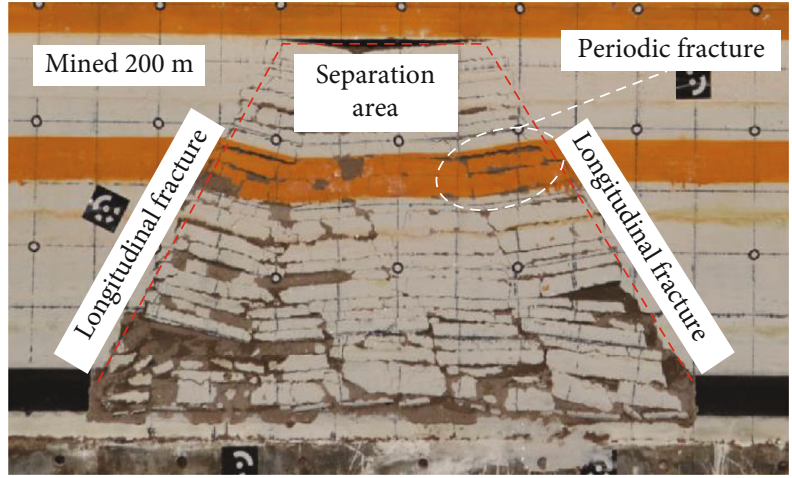

(b) Periodic fracture of the lower key strata

FIGURE 6: Fracture characteristics of lower key strata.

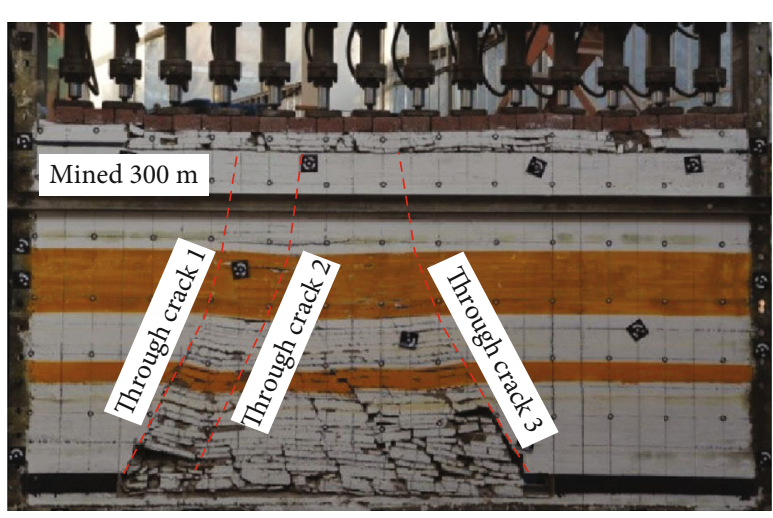

(a) Primary fracture of the higher key strata

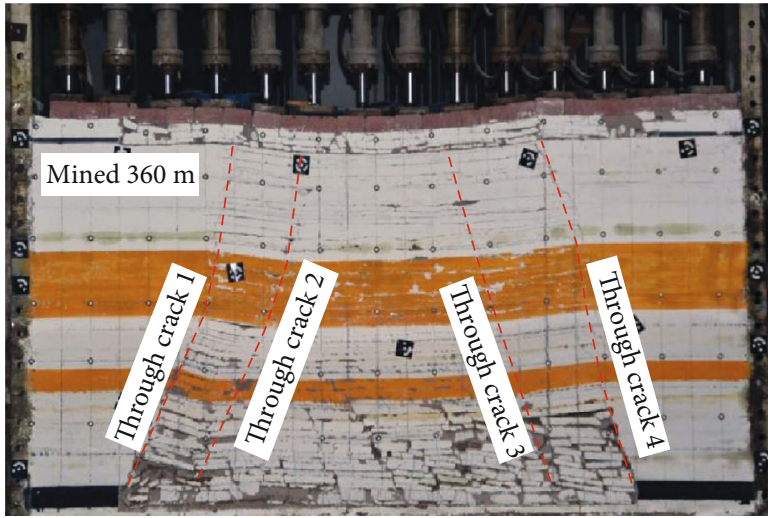

(b) Periodic fracture of the higher key strata

FIGURE 7: Fracture characteristics of the higher key strata.

lower key strata fractures synchronously, and the gasconducting fracture develops in the soft rock layer and extends to the bottom of the higher key strata. If the higher key strata does not fracture or lose stability (the distance of panel advance is insufficient), the gas-conducting fracture in the higher key strata and its control soft rock layer cannot connect with the Jurassic gob, and the gas downward leakage will not be caused, as shown in Figure 8.

With the continuous advance of the panel, if the higher key strata is fractured along with the mining, the soft rock layer at the upper part of the higher key strata is simultaneously fractured along with the higher key 


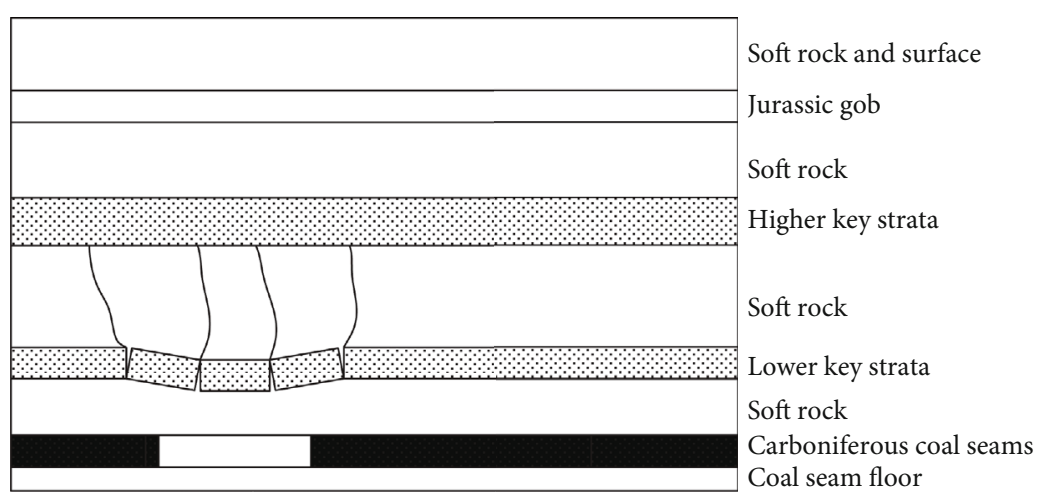

FIGURE 8: Distribution diagram of gas-conducting fracture field before fracture of the higher key strata.

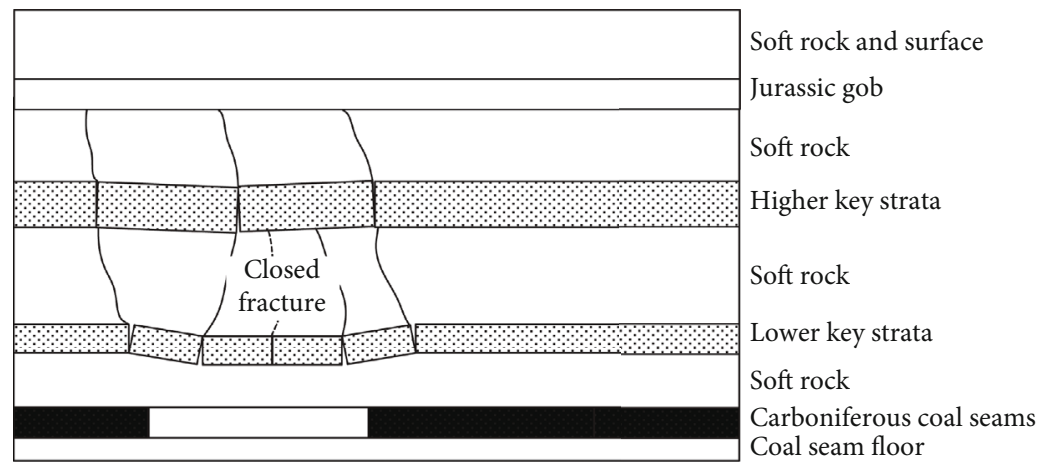

Figure 9: Distribution diagram of gas-conducting fracture field in the first fracture of the higher key strata.

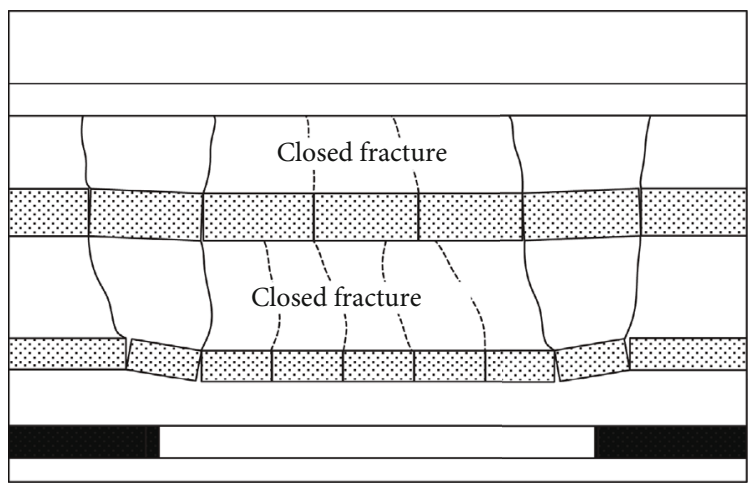

Soft rock and surface
Jurassic gob
Soft rock
Higher key strata
Soft rock
Lower key strata
Soft rock
Carboniferous coal seams
Coal seam floor

FIGURE 10: Distribution diagram of gas-conducting fracture field during periodic fracture of the higher key layer.

strata, the fracture field at the upper part of the higher key strata connects the Jurassic gob and forms an effective gas pathway together with the fractures in the control area of the lower key strata, and the harmful gas in the Jurassic gob enters downward along with the effective gas pathway to the gob open-off cut and the panel, as shown in Figure 9. It should be noted that with the development of mining activities, the lower key strata has a periodic fracture and settlement rotation. The gas-conducting fracture (including the gas-conducting fracture in the upper control soft rock layer) behind the panel is closed with the settlement contact, and the gas-conducting capacity is sharply reduced. However, the new broken rock block forms the new gas-conducting fracture in front of the panel. If the closed fracture is not considered, with the periodic fracture of the lower key strata, the number and capacity of the effective gas-conducting fractures in the lower key strata and its overburden strata do not decrease with the closing of the latter fractures.

When the higher key strata fractures periodically with the mining, the gas-conducting fracture in the soft layer, lower, and higher key strata in the middle of the gob gradually close and disappear, and the gas-conducting ability decreases sharply. The mining fracture of the overburden strata near the open-off cut and the panel are developed, and four effective gas leakage pathways are formed in the lower key strata, 
the higher key strata, and the soft strata controlled by the overburden strata, as shown in Figure 10.

5.2. Analysis of the Influence of Key Strata on the Gas Downward Leakage Law. Under the mining condition of dual-system coal seam in Datong mining area, the main reason for periodic downward leakage of harmful gas in Jurassic gob is the fracture and rotation of the higher key strata. Under the condition of nonpressure and small mining pressure, the blocks in the higher key strata above the panel turn in the reverse direction, the higher key strata and its upper gas-conducting fracture close rapidly, resulting in the disappearance of the effective gas pathway. Harmful gases in the Jurassic gob are mainly discharged into the gob of carboniferous coal seam through the effective gas pathway above the open-off cut. In the closed state, there is stable harmful gas discharge into the panel through the gob of Carboniferous system. In the large periodic mining pressure, the rotation and fracture of the higher key strata result in the formation of new effective gas-conducting pathways, and the harmful gas in the panel of Carboniferous system increases sharply.

To sum up, under the condition of dual-system coal seam mining in Datong mining area, when the Carboniferous coal seam is mined to the lower part of the Jurassic gob, if there is strong mining pressure in the panel, effective measures such as the use of pressure equalizing ventilation system should be taken timely to eliminate the hidden danger of harmful gas downward leakage from the Jurassic gob to the panel.

\section{Conclusions}

(1) The change of CO concentration in the upper corner of panel 8309 shows periodic change, which is consistent with the mining pressure law. In the case of nonpressure and small periodic mining pressure, $\mathrm{CO}$ concentration is low, while in the case of large periodic mining pressure, $\mathrm{CO}$ concentration increases significantly.

(2) The main cause of harmful gas downward leakage in the Jurassic gob is through fractures produced by the fracture of the higher key strata. If the higher key strata fractures in the coal mining in the Carboniferous system, the through fracture connecting the Jurassic gob will be formed above the open-off cut and the panel.

(3) Under the mining condition of dual-system coal seam in Datong mining area, the main reason for periodic downward leakage of harmful gas in Jurassic gob is the fracture and rotation of higher key strata. When the Jurassic gob is overlying on the Carboniferous coal seam in the mining process, once the strong mine pressure appears in the panel, effective measures should be taken timely to eliminate the hidden danger of harmful gas downward leakage from the Jurassic gob to the panel.

\section{Data Availability}

The data used to support the findings of this study are included within the article.

\section{Conflicts of Interest}

The authors declare that they have no conflicts of interest.

\section{Acknowledgments}

This work was supported by the National Natural Science Foundation of China (U1904128 and 51774110, 51704095) and Program for Science \& Technology Innovation Talents in Universities of Henan Province (19HASTIT047), the Fundamental Research Funds for the Universities of Henan Province (NSFRF200302), and the Foundation for Higher Education Key Research Project by Henan Province (19A130001).

\section{References}

[1] B. Yu, "Study on fully mechanized coal mining technology in passed 40 years in Datong mining area," Journal of China Coal Society, vol. 32, pp. 1772-1777, 2010.

[2] B. Yu, "Behaviors of overlying strata in extra-thick coal seams using top-coal caving method," Journal of Rock Mechanics and Geotechnical Engineering, vol. 8, no. 2, pp. 238-247, 2016.

[3] D. Ma, J. Wang, X. Cai et al., "Effects of height/diameter ratio on failure and damage properties of granite under coupled bending and splitting deformation," Engineering Fracture Mechanics, vol. 220, p. 106640, 2019.

[4] Y. Chen, H. W. Zhang, Z. J. Zhu, B. Yu, and L. J. Huo, "Research on the law overburden movement and failure under the influence of double period coal seam mining," The Chinese Journal of Geological Hazard and Control, vol. 32, pp. 67-73, 2014.

[5] M. Bai and D. Elsworth, "Some aspects of mining under aquifers in China," Mining Science and Technology, vol. 10, no. 1, pp. 81-91, 1990.

[6] V. Palchik, "Influence of physical characteristics of weak rock mass on height of caved zone over abandoned subsurface coal mines," Environmental Geology, vol. 42, no. 1, pp. 92-101, 2002.

[7] T. Q. Liu, Theory and technology of optimal design of outcrop coal pillar, Coal Industry, Beijing, 1981.

[8] State Bureau of Coal Industry, Rules for coal pillar reservation and coal pressure mining in buildings, gas, railways and main shafts, Coal Industry, Beijing, 2000.

[9] D. Ma, J. Wang, and Z. Li, "Effect of particle erosion on mining-induced water inrush hazard of karst collapse pillar," Environmental Science and Pollution Research, vol. 26, no. 19, pp. 19719-19728, 2019.

[10] W. Xu, Y. C. Xia, and R. J. Du, "Study on three properties of the empirical formula for estimating the height of waterflowing fractured zone," Mining Research and Development, vol. 33, pp. 63-67, 2013.

[11] M. M. Singh and F. S. Kendorski, "Strata disturbance prediction for mining beneath surface water and waste impoundments," International Journal of Rock Mechanics and Mining Sciences \& Geomechanics Abstracts, vol. 20, no. 1, p. a13, 1983. 
[12] M. G. Qian, S. P. Wu, and J. L. Xu, Mine pressure and strata control, China University of Mining and Technology, Xuzhou, 2010.

[13] J. Ju and J. Xu, "Structural characteristics of key strata and strata behaviour of a fully mechanized longwall face with 7.0m height chocks," International Journal of Rock Mechanics and Mining Sciences, vol. 58, pp. 46-54, 2013.

[14] Z. Li, J. Xu, J. Ju, W. Zhu, and J. Xu, “The effects of the rotational speed of voussoir beam structures formed by key strata on the ground pressure of stopes," International Journal of Rock Mechanics and Mining Sciences, vol. 108, pp. 67-79, 2018.

[15] Z. Zhang, J. Xu, W. Zhu, and Z. Shan, "Simulation research on the influence of eroded primary key strata on dynamic strata pressure of shallow coal seams in gully terrain," International Journal of Mining Science and Technology, vol. 22, no. 1, pp. 51-55, 2012.

[16] T. Kuang, Z. Li, W. Zhu et al., "The impact of key strata movement on ground pressure behaviour in the Datong coalfield," International Journal of Rock Mechanics and Mining Sciences, vol. 119, pp. 193-204, 2019.

[17] X. X. Miao, H. Pu, and H. B. Bai, "Principle of water-resisting key strata and its application in water-preserved mining," Journal of China University of Mining and Technology, vol. 37, pp. 1-4, 2008.

[18] L. WANG, X. MIAO, Y. WU, J. SUN, and H. YANG, "Discrimination conditions and process of water-resistant key strata," Mining Science and Technology (China), vol. 20, no. 2, pp. 224-229, 2010.

[19] M. M. Feng, X. B. MAO, H. B. Bai, and X. X. Miao, "Analysis of water insulating effect of compound water-resisting key strata in deep mining," Journal of China University of Mining and Technology, vol. 17, no. 1, pp. 1-5, 2007.

[20] D. Ma, M. Rezania, H. S. Yu, and H. B. Bai, "Variations of hydraulic properties of granular sandstones during water inrush: effect of small particle migration," Engineering Geology, vol. 217, pp. 61-70, 2017.

[21] J. L. Xu, W. B. Zhu, and X. Z. Wang, "New method to predict the height of fractured water-conducting zone by location of key strata," Journal of China Coal Society, vol. 37, pp. 762$769,2012$.

[22] X. Z. Wang, W. T. Liu, and Z. G. Wang, "Effects of primary key stratum location on height of water flowing fracture zone," Chinese Journal of Rock Mechanics and Engineering, vol. 28, pp. 380-385, 2009.

[23] D. Ma, H. Duan, W. Liu, X. Ma, and M. Tao, "Water- sediment two-phase flow inrush hazard in rock fractures of overburden strata during coal mining," Mine Water and the Environment, vol. 39, no. 2, pp. 308-319, 2020.

[24] F. Du and R. Gao, "Development patterns of fractured waterconducting zones in longwall mining of thick coal seams-a case study on safe mining under the Zhuozhang river," Energies, vol. 10, no. 11, p. 1856, 2017.

[25] M. Tu and B. J. Fu, "Analysis of the effect of key strata structure on relief-pressure mining in protective seam," Journal of Mining and Safety Engineering, vol. 28, pp. 536-541, 2011.

[26] Q. D. Qu, J. L. Xu, and M. G. Qian, "Study on the influence of key strata movement on gas emission of adjacent layers," Chinese Journal of Rock Mechanics and Engineering, vol. 26, pp. 1478-1484, 2007.

[27] R. L. Wu, "Effects of key stratum on the scope of the "three zones" of gas pressure relief and migration in coal seam group mining," Journal of China Coal Society, vol. 38, pp. 924-929, 2013.

[28] D. Ma, H. Duan, X. Li, Z. Li, Z. Zhou, and T. Li, "Effects of seepage-induced erosion on nonlinear hydraulic properties of broken red sandstones," Tunnelling and Underground Space Technology, vol. 91, p. 102993, 2019.

[29] G. Si, S. Durucan, J.-Q. Shi, A. Korre, and W. Cao, "Parametric analysis of slotting operation induced failure zones to stimulate low permeability coal seams," Rock Mechanics and Rock Engineering, vol. 52, no. 1, pp. 163-182, 2019.

[30] Z. Yangsheng, Q. Fang, W. Zhijun, Z. Yuan, L. Weiguo, and M. Qiaorong, "Experimental investigation on correlation between permeability variation and pore structure during coal pyrolysis," Transport in Porous Media, vol. 82, no. 2, pp. 401412, 2010.

[31] G. X. Wang, P. Massarotto, and V. Rudolph, "An improved permeability model of coal for coalbed methane recovery and CO2 geosequestration," International Journal of Coal Geology, vol. 77, no. 1-2, pp. 127-136, 2009.

[32] Y. Xue, T. Teng, F. Dang, Z. Ma, S. Wang, and H. Xue, "Productivity analysis of fractured wells in reservoir of hydrogen and carbon based on dual-porosity medium model," International Journal of Hydrogen Energy, vol. 45, no. 39, pp. 20240-20249, 2020.

[33] Z. Z. Cao, P. Xu, Z. H. Li, M. X. Zhang, Y. Zhao, and W. L. Shen, "Joint bearing mechanism of coal pillar and backfilling body in roadway backfilling mining technology," CMC-Computers Materials \& Continua, vol. 54, no. 2, pp. 137-159, 2018.

[34] W. L. Shen, J. B. Bai, W. F. Li, and X. Y. Wang, "Prediction of relative displacement for entry roof with weak plane under the effect of mining abutment stress,", Tunnelling and Underground Space Technology, vol. 71, pp. 309-317, 2018.

[35] J. Liu, X. Liang, Y. Xue, K. Yao, and Y. Fu, "Numerical evaluation on multiphase flow and heat transfer during thermal stimulation enhanced shale gas recovery," Applied Thermal Engineering, vol. 178, p. 115554, 2020.

[36] Y. Xue, P. G. Ranjith, F. Dang et al., "Analysis of Deformation, Permeability and Energy Evolution Characteristics of Coal Mass Around Borehole After Excavation," Natural Resources Research, vol. 29, 2020.

[37] D. Ma, H. Y. Duan, Q. Zhang et al., A Numerical Gas Fracturing Model of Coupled Thermal, Flowing and Mechanical Effects, CMC-Computers Materials \& Continua, 2010.

[38] Y. Li, L. She, L. Wen, and Q. Zhang, "Sensitivity analysis of drilling parameters in rock rotary drilling process based on orthogonal test method," Engineering Geology, vol. 270, p. 105576, 2020. 